Annals of Warsaw University of Life Sciences - SGGW

Agriculture No 69 (Agricultural and Forest Engineering) 2017: 51-59

(Ann. Warsaw Univ. of Life Sci. - SGGW, Agricult. 69, 2017)

DOI 10.22630/AAFE.2017.6

\title{
Noise assessment for selected seed extraction plants
}

\author{
MONIKA ANISZEWSKA, ARKADIUSZ GENDEK, JAN SKARŻYŃSKI \\ Department of Agricultural and Forest Engineering, Warsaw University of Life Sciences - SGGW
}

\begin{abstract}
Noise assessment for selected seed extraction plants. In the process of seed extraction, extraction plant staff is exposed to work in onerous conditions due to noise. The article outlines the results of noise measurements in the cone extraction hall and office rooms within the extraction plant operating in the Czarna Białostocka and Grotniki forest districts. The measurements were carried out in accordance with standard PN-EN ISO 11201:1999, at work stations, while the extraction cabinets, separators and thresher riddle were in use for the purpose of seed extraction and processing. The results obtained were confronted with the applicable standards and provisions concerning admissible noise levels at work stations. The average noise value $\left(L_{\text {Aeq, },}\right)$ in the production hall equalled $83.7 \pm 2.0 \mathrm{~dB}(\mathrm{~A})$ in Czarna Białostocka and $81.2 \pm 1.4 \mathrm{~dB}(\mathrm{~A})$ in Grotniki. In both extraction plants, these values should be considered onerous for the employees and the risk due to exposure to noise should be considered moderate. The most significant source of noise emission in the Czarna Białostocka seed extraction plant is the mechanical seed thresher riddle, while in Grotniki, the biggest noise was produced by the extractor matched with the thresher riddle. The respective values of $55.9 \pm 0.2$ and 42.5 $\pm 0.9 \mathrm{~dB}(\mathrm{~A})$ were obtained in the office rooms immediately adjacent to the seed extraction hall. According to these values, the risk of exposure to noise in office rooms within the plant is low.
\end{abstract}

Key words: noise, cones, exposure assessment, seed extraction, extraction equipment

\section{INTRODUCTION}

Noise is an audible sound that is detrimental or onerous to health, i.e. within the range from $16 \mathrm{~Hz}$ to $16 \mathrm{kHz}$. Excessive noise has negative impact on people as, depending on the sound level, it leads to insignificant, average or significant damage in the body, including the auditory system. Exposure to lowintensity noise, of ca. $55 \mathrm{~dB}$, may cause nervous excitability, annoyance or deterioration of memory, while higher values, from $75 \mathrm{~dB}$, lead to stress, or may even cause damage to hearing (above $115 \mathrm{~dB}$ ) [Mikulski et al. n.d.]. Statistical data show that noise [Pawlaczyk-Łuszczyńska et al. 2001, 2007] causes occupational disease, for which oftentimes there is no rehabilitation. The tests concerning factual exposure to noise in the working environment conducted in Poland show that $41 \%$ of the nearly 700 thousand people working in hazardous conditions were exposed to noise exceeding the admissible values [Sadowski 2013]. Standards are being introduced to define the admissible noise levels in the working environment, methods 
of their measurements and requirements concerning the measuring apparatus [PN-N-01307:1994]. Noise is defined by the following parameters: exposure to noise in an eight-hour or weekly working time and the corresponding daily or weekly exposure, maximum A - weighted sound level and peak C - weighted sound level.

In practice, noise is measured by a direct and indirect method. While the first one consists in continuous noise measurements, in the latter measurements are performed throughout a short period of time and the values obtained are converted as appropriate.

In order to reduce the risk related to audible noise, infrasound noise or ultrasound noise, dedicated technical and organizational measures are used, which to some degree protect the employees against the detrimental effects of the noise, but do not eliminate the root cause of the risk. Among the most frequently used technical measures are hearing protectors, sound mufflers, noise screens, soundproof chambers, machine isolation from the floor etc. Organizational sound-reducing methods, in turn, include: separation of noise-generating machines and their installation in separate rooms, at a relevant distance from other work stations, breaks at work, rotation of staff at the work stations, appropriate arrangement of work stations in accordance with their acoustics [Wilkus 2007, Ingielewicz and Zagubień 2013, Sadowski 2013, Górski 2014].
Noise tests and measurements have been the subject of writings of numerous authors from various sectors of the petroleum, gas, drilling, wood, forest and transport industries [Augustyńska et al. 2000, Bednarz and Urba 2003, Macuda 2008]. The noise generated by machines and fixed or transportable devices was assessed through testing their impact on the working environment [Augustyńska et al. 2000, Mikulski and Augustynska 2000, Kaczmarska and Mikulski 2003, Adamczyk 2004, Golec et al. 2006, Tomaszewski and Orczyk 2007, Wilkus 2007, Skarżyński et al. 2009, Ingielewicz and Zagubień 2013, Skarżyński and Lipiński 2013, Górski 2014].

The literature lacks data concerning the level of noise generated by machinery in commercial seed extraction plants, which are basically fitted with devices for preliminary cone cleaning, extraction machines, thresher riddles, dewinging machines, seed driers, seed cleaning devices and separators, which are operated simultaneously within the production hall during seed extraction and processing [Sarnowska and Więsik 1997a, b, 1998]. As working conditions in the seed extraction plants during the extraction season are onerous, the authors assessed and determined the admissible exposure to noise of employees of the seed extraction plants of the Czarna Białostocka and Grotniki forest districts, i.e. two of the sixteen plants of this type operating in Poland [Aniszewska and Gendek 2014, 2016a, b, Aniszewska and Kuszpit 2015]. 


\section{METHODOLOGY OF TESTS}

Noise measurement tests were carried out in two commercial seed extraction plants in the forest districts of Czarna Białostocka (Regional Directorate of State Forests in Białystok) and Grotniki (Regional Directorate of State Forests in Łódź) [Aniszewska and Gendek 2014, 2016a, b, Aniszewska and Kuszpit 2015]. Both seed extraction plants are modern plants. The first one was established in 1996 and the other in 2001. The seed extraction plants are fitted with fully automated devices that are compliant with applicable standards.
Noise at the work stations in the production hall was measured with an indirect method, while seed-extracting machines were being in use. The hall in the extraction plant in Czarna Białostocka covers the area of $900 \mathrm{~m}^{2}(30 \times 30 \mathrm{~m})$ and is six-meter high. The hall in Grotniki, in turn, covers $180 \mathrm{~m}^{2}(30 \times 6 \mathrm{~m})$ and its height equals $5 \mathrm{~m}$. In Grotniki and Czarna Białostocka, the building has a solid roof, with no skylights, and rendered walls. The machines used in the process were installed on a concrete floor surfacing. The layout of the rooms, distribution of machines and location of the measuring device are presented on Figure 1. $\mathrm{a}$

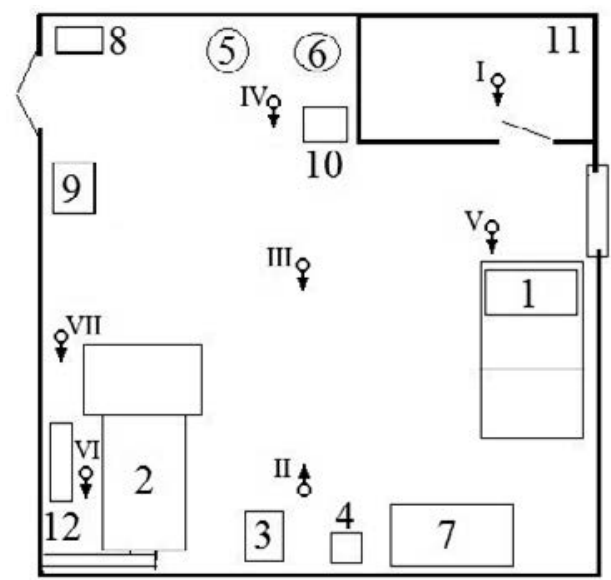

1 - extraction cabinet, 2 - device for mechanical seed extraction (thresher riddle), 3 - seed dewinging device, 4 - screen seed separator, 5 - water seed separator, 6 - pressure seed separator, 7 - seed drier, 8 - air seed separator, 9 - larch seed extraction drum, 10 - seed pickling machine, 11 - office room, 12 - cone feed channel, 13 - opened cones roller conveyor, 14 - device for preliminary cleaning of cones

b

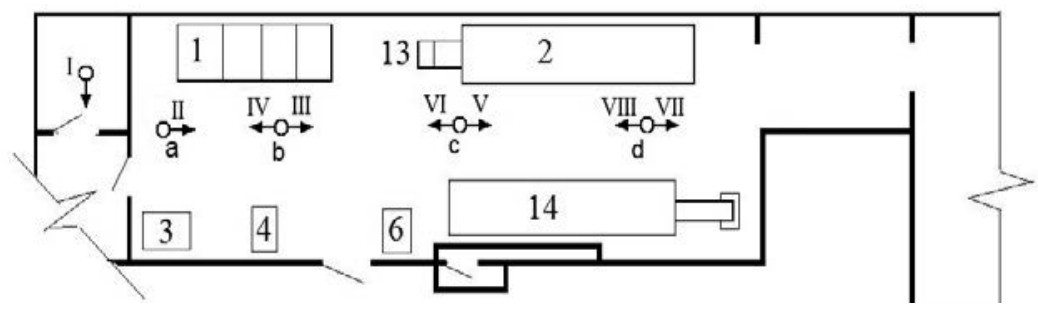

FIGURE 1. Scheme of the production hall: $\mathrm{a}$ - in the extraction plant in Czarna Białostocka with noise measurement points marked: in the hall (II-VII); b - in the extraction plant in Grotniki with noise measurement points and directions marked: in the office room (I) and in the production hall (a-d) [Więsik and Aniszewska 2012] 
Noise measurements were also carried out in the extraction plants administration office (in Grotniki, the office was located within the hall, while in Czarna Białostocka it was adjacent to the production hall).

The noise was measured in accordance with the procedure described in standard PN-EN ISO 11201:1999 The Brüel \& Kjær soundlevel meter, type 2231, was used for the measurements. The device enabled equivalent noise measurement within 8 of work $\left(L_{\text {AeqT }}\right)$, as well as the maximum $\left(L_{\text {Amax }}\right)$ and peak $\left(L_{\text {Cpeak }}\right)$ sound levels with an accuracy of $0.1 \mathrm{~dB}$. The microphone of the measuring device was installed $1.55 \mathrm{~m}$ above the floor (in the production hall) and $0.8 \mathrm{~m}$ above the seat of the chair, next to the employee's desk (in the office room).

In the extraction plant in Czarna Białostocka, the sound level was measured at six points within the hall and at one point in the office (Fig. 1a). During the noise measurements in the hall and in the office, at all measurement points, the microphone was at all times facing one direction.

In the extraction plant in Grotniki, the noise was measured at four points within the hall (Fig. 1b, points a-d) and at one point in the office room (Fig. 1b, point I). At measurement points b, c, d the microphone was oriented longways the hall, forwards and backwards. At measurement points a, the microphone was facing only one direction.
In all seed extraction plants and at all measurement points, the noise measurements were repeated five times, with measurement time of $15 \mathrm{~s}$. Statistical analyses of the test results were performed in Statistica v.12, with the assumed statistical significance $\alpha=0.05$.

\section{RESULTS}

The average noise measurement values for the production hall, during the process of seed extraction in the Czarna Białostocka and Grotniki plants are presented in the table. The work station number in the table corresponds to the location of the microphone, in accordance with Figure 1.

The results of noise measurements for the average values $L_{\text {Aeq, }}[\mathrm{dB}(\mathrm{A})]$ showed that the halls in both extraction plants are exposed to risk related to noise. In accordance with the algorithm used for the calculation of occupational risk in a three-step scale (Fig. 2), both in the extraction plant in Grotniki [average result: $81.2 \mathrm{~dB}(\mathrm{~A})]$ and in Czarna Białostocka [83.7 dB(A)], the exposure to risk is average.

At one point in the extraction plant in Czarna Białostocka (measurement $\mathrm{V}$ on Fig. 1a), the measurements showed noise level exceeding $85 \mathrm{~dB}$, which means that exposure to risk is high. Differences between the highest and the lowest values equal $6.6 \mathrm{~dB}$ for the extraction plant in Czarna Białostocka and $7.9 \mathrm{~dB}$ for Grotniki. 
TABLE. Average noise level (AVG) with standard deviation $( \pm S D)$ and minimum and maximum values for the Czarna Białostocka and Grotniki extraction plants

\begin{tabular}{|c|c|c|c|c|c|c|c|c|c|}
\hline \multirow{2}{*}{$\begin{array}{l}\text { Work } \\
\text { station } \\
\text { number }\end{array}$} & \multicolumn{3}{|c|}{$\begin{array}{c}L_{\text {Aeq, } \mathrm{T}} \\
\mathrm{dB}(\mathrm{A})\end{array}$} & \multicolumn{3}{|c|}{$\begin{array}{c}L_{\mathrm{Amax}} \\
\mathrm{dB}(\mathrm{A})\end{array}$} & \multicolumn{3}{|c|}{$\begin{array}{l}L_{\text {Cpeak }} \\
\mathrm{dB}(\mathrm{C})\end{array}$} \\
\hline & $A V G \pm S D$ & $\min$ & $\max$ & $A V G \pm S D$ & $\min$ & $\max$ & $A V G \pm S D$ & $\min$ & $\max$ \\
\hline \multicolumn{10}{|c|}{ Czarna Białostocka } \\
\hline II & $83.5 \pm 0.5$ & 83.0 & 84.2 & $85.8 \pm 2.0$ & 83.8 & 88.5 & $107.2 \pm 7.0$ & 100.4 & 117.2 \\
\hline III & $82.7 \pm 0.2$ & 82.6 & 83.0 & $83.7 \pm 0.4$ & 83.3 & 84.4 & $104.0 \pm 4.5$ & 100.2 & 109.6 \\
\hline IV & $81.2 \pm 0.2$ & 80.8 & 81.4 & $82.4 \pm 0.5$ & 81.7 & 83.0 & $101.9 \pm 3.9$ & 98.7 & 106.4 \\
\hline $\mathrm{V}$ & $82.7 \pm 0.2$ & 82.5 & 83.0 & $84.1 \pm 0.4$ & 83.7 & 84.6 & $102.8 \pm 4.5$ & 99.2 & 108.2 \\
\hline VI & $87.2 \pm 0.2$ & 87.0 & 87.4 & $88.3 \pm 0.3$ & 87.9 & 88.7 & $110.1 \pm 4.1$ & 105.3 & 113.7 \\
\hline VII & $84.9 \pm 0.1$ & 84.9 & 85.0 & $86.8 \pm 0.2$ & 86.7 & 87.1 & $107.5 \pm 4.7$ & 103.6 & 112.7 \\
\hline Overall & $83.7 \pm 2.0$ & 80.8 & 87.4 & $85.2 \pm 2.2$ & 81.7 & 88.7 & $105.6 \pm 5.3$ & 98.7 & 117.2 \\
\hline Office I & $55.9 \pm 0.2$ & 55.7 & 56.2 & $56.8 \pm 0,2$ & 56.6 & 57.0 & $81.4 \pm 3.8$ & 77.1 & 85.1 \\
\hline \multicolumn{10}{|c|}{ Grotniki } \\
\hline II & $80.9 \pm 0.2$ & 80.6 & 81.1 & $83.3 \pm 1.5$ & 81.9 & 85.0 & $105.3 \pm 8.6$ & 99.6 & 119.1 \\
\hline III & $80.6 \pm 0.1$ & 80.4 & 80.7 & $82.0 \pm 0.3$ & 81.5 & 82.2 & $104.9 \pm 4.9$ & 99.6 & 110.1 \\
\hline IV & $81.2 \pm 0.2$ & 81.1 & 81.3 & $82.9 \pm 0.2$ & 82.7 & 83.1 & $104.7 \pm 4.8$ & 99.4 & 109.3 \\
\hline $\mathrm{V}$ & $80.6 \pm 0.1$ & 80.6 & 80.7 & $82.0 \pm 0.2$ & 81.8 & 82.2 & $104.1 \pm 4.0$ & 100.3 & 108.9 \\
\hline VI & $81.0 \pm 0.1$ & 80.9 & 81.0 & $82.2 \pm 0.2$ & 82.0 & 82.5 & $104.3 \pm 4.5$ & 100.2 & 109.7 \\
\hline VII & $80.5 \pm 0.1$ & 80.4 & 80.5 & $81.9 \pm 0.2$ & 81.5 & 82.1 & $104.1 \pm 3.8$ & 99.9 & 107.8 \\
\hline VIII & $83.5 \pm 2.8$ & 81.1 & 88.3 & $88.5 \pm 6.4$ & 84.5 & 99.7 & $102.2 \pm 4.0$ & 98.9 & 107.2 \\
\hline Overall & $81.2 \pm 1.4$ & 80.4 & 88.3 & $83.3 \pm 3.2$ & 81.5 & 99.7 & $104.2 \pm 4.8$ & 98.9 & 119.1 \\
\hline Office I & $42.5 \pm 0.9$ & 41.9 & 44.1 & $44.6 \pm 1.4$ & 43.4 & 46.7 & $78.0 \pm 3.9$ & 72.1 & 81.7 \\
\hline
\end{tabular}

FIGURE 2. Algorithm used to calculate occupational risk related to noise exposure as a factor detrimental to the organ of hearing (three-step scale) [PN-N$-18002: 2011]$

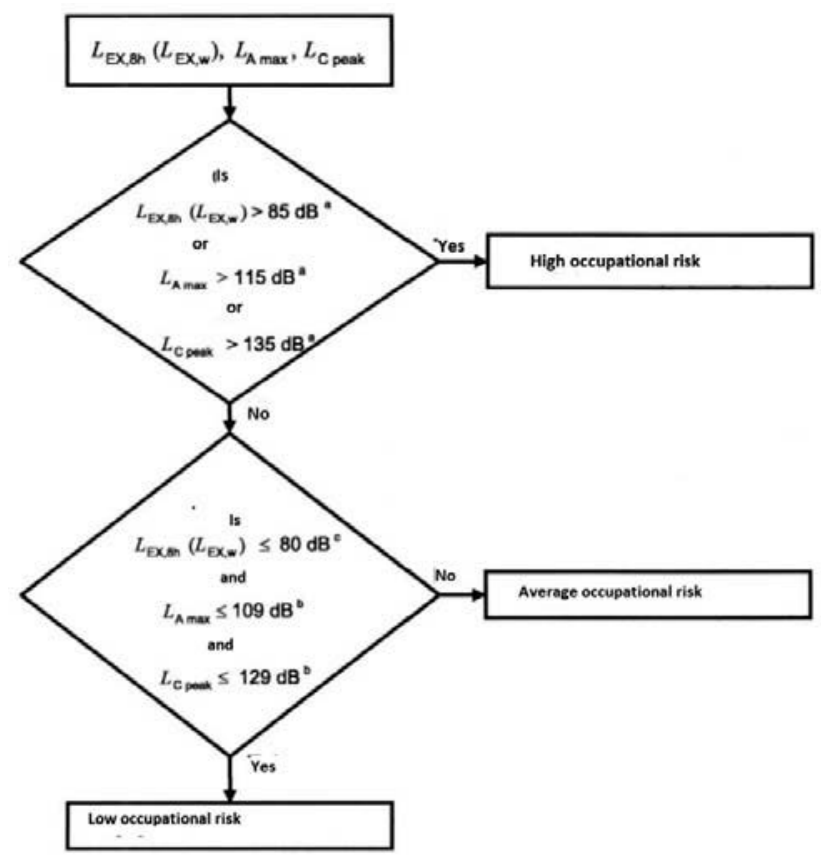


On average, the noise measured $\left(L_{\text {Amax }}\right)$ is by ca. $2 \mathrm{~dB}$ lower for the Grotniki extraction plant than for the other plant. Nevertheless, when analysing individual measurements, it was concluded that the highest noise level (99.7 dB) in the Grotniki extraction plant was reported for measurement point VIII (Fig. 1b). The measurement was made after starting the extractor matched with the mechanical cone seed thresher riddle. In comparison, the noise level registered in the hall within the Czarna Białostocka extraction plant near the machine used for the same technological operation was lower by $1 \mathrm{~dB}-88.7 \mathrm{~dB}$ (measurement V on Fig. 1a). The lowest noise level $\left(L_{\text {Amax }}\right)$ in the production hall was recorded at point III in Grotniki (81.5 dB) and Czarna Białostocka (81.7 dB). In Grotniki, the microphone was installed at the height of the closed door of the extraction cabinet, while in Czarna Białostocka, it was near the water and pressure seed separator and the seed pickling machine. It must be noted, though, that for technical reasons, during the measurement the seed pickling machine was off.

From the point of view of the employees, the most important noise-defining parameter for the extraction plant is $L_{\text {Aeq,T }}$. The average level of noise in the Czarna Białostocka plant equalled 83.7 $\pm 2.0 \mathrm{~dB}$ and was by $2.5 \mathrm{~dB}$ higher than in Grotniki. This means that the audible noise accompanying seed extraction in Czarna Białostocka was almost twice as high as in Grotniki. In both seed extraction plants, the noise is mostly generated by the pollutant extractor and the thresher riddle.

When comparing noise $L_{\text {Amax }}\left(F_{(1.63)}=\right.$ $=7.82 ; P=0.0068)$ and $L_{\text {Aeq, },}\left(F_{(1.63)}=\right.$ $=37.37 ; P<0.0001)$ in both extraction plants, statistical analyses showed significant differences. In the seed extraction hall in Czarna Białostocka the noise level is higher than in Grotniki.

Average noise analysis $\left(L_{\text {Cpeak }}\right)$ in both extraction plants showed that the value obtained was by $1.4 \mathrm{~dB}$ higher in Czarna Białostocka. Nevertheless, the highest noise was reported in the extraction plant in Grotniki, at measurement point II - $119.1 \mathrm{~dB}$ (Fig. 1b), where the measurement of noise was performed towards the interior of the hall, at the point of installation of the extraction cabinet driver mechanisms. In the hall of the other plant, the highest noise level $(117.2 \mathrm{~dB})$ was marked at point I (Fig. 1a). The measurement was performed near the dewinging machines and seed separators.

The analyses of homogeneity of the variance of noise level comparison between the extraction plants in question showed no statistically significant differences for $L_{\text {Cpeak }}\left(F_{(1.63)}=1.16 ; P=0.2850\right)$ and the average results for both plants can be considered a homogenous group. The average value in the homogenous group equals $104.85 \pm 5.05$.

In the office rooms in both seed extraction plants the noise measured $\left(L_{\text {Aeq, } \mathrm{T}}\right)$ was lower than $80 \mathrm{~dB}$, which means that the risk stemming from exposure 
to noise is low. The average result was $55.9 \pm 0.2 \mathrm{~dB}$ for the extraction plant in Czarna Białostocka and $42.5 \pm 0.9 \mathrm{~dB}$ for Grotniki. As showed by tests carried out, the noise in Grotniki was lower on average by $8 \mathrm{~dB}$. The average level of noise $L_{\text {Amax }}$ in the office room equalled $56.8 \pm 0.2 \mathrm{~dB}$ in the first plant (in Czarna Białostocka) and $44.6 \pm 1.4 \mathrm{~dB}$ in the latter (Grotniki). When it comes to $L_{\text {Cpeak }}$, the results for the plants equalled $81.4 \pm 3.8 \mathrm{~dB}$ and $78.0 \pm 3.9 \mathrm{~dB}$, respectively. The maximum $L_{\text {Cpeak }}$ was 85.1 and $81.7 \mathrm{~dB}$.

In the research carried out by Kaczmarska and Mikulski [2003], the level of audible noise $L_{\text {Aeq,T }} \mathrm{dB}(\mathrm{A})$ in office rooms varied from 34.3 to $49.1 \mathrm{~dB}$ (42.6 dB on average). Similar results were obtained for the Grotniki plant [42.5 $\mathrm{dB}(\mathrm{A})]$. When it comes to noise in the office room of the plant in Czarna Białostocka, it was much higher and equalled $55.9 \mathrm{~dB}(\mathrm{~A})$, which is marginally above the admissible value of $55 \mathrm{~dB}(\mathrm{~A})$ for administrative and office rooms, as defined in standard PN-N-01307:1994. Such a big difference in the noise level [13.4 dB(A)] results from the fact that the office room in Czarna Białostocka was built from gypsum boards directly within the production hall, while in Grotniki, it is located outside of the hall and adheres to a hollow-brick wall.

\section{CONCLUSIONS}

The tests performed show that at one point in the extraction plant in Czarna Białostocka, the noise exposure level obtained in the measurements exceeds the admissible value of $85 \mathrm{~dB}$, while the maximum $\mathrm{dB}(\mathrm{A})$ and peak $\mathrm{dB}(\mathrm{C})$ sound levels measured do not reach beyond the permitted threshold of $115 \mathrm{~dB}(\mathrm{~A})$ and $135 \mathrm{~dB}(\mathrm{~A})$ respectively. Therefore, it can be concluded that noise within the production plant can be onerous and may be the cause of distraction and stress, especially in those working near the machine used for seed threshing from cones or in the vicinity of an active extractor.

The analysis of noise measurement in the production hall showed that the noise $\left(L_{\text {Aeq,T }}\right)$ registered during works in the commercial extraction plant in Czarna Białostocka is higher by ca. $2.5 \mathrm{~dB}$ than in Grotniki. Analogically, higher $L_{\text {Amax }}$ and $L_{\text {Cpeak }}$ values (by 1.9 and $1.4 \mathrm{~dB}$, respectively) were reported in Grotniki. In both extraction plants, the main source of noise is the pollutant extract and the thresher riddle.

The estimated risk stemming from exposure to risk in both extraction plants is moderate. To reduce the risk of noise and, thus, improve the comfort of work in the production hall, the solutions listed below can be applied. Firstly, a transportable or fixed noise screen can be placed in the Czarna Białostocka extraction plant, near the thresher riddle. Secondly, the sound absorption properties of the hall can be improved by cladding the walls and floors with appropriate sound absorbing materials, which may be particularly helpful near the noise generating machine described 
above. In Grotniki, the extract can be protected with a sound absorbing insulating material, to disperse and damp the noise and, therefore, reduce its impact on the employees. Nevertheless, additional tests are needed to assess whether the solutions proposed will improve working conditions and reduce noise generated during seed extraction. The use of personal protection measures should be recommended in both extraction plants (hearing protectors for employees staying within the production hall).

\section{REFERENCES}

ADAMCZYK F. 2004: Rozprzestrzenianie się hałasu (wybrane częstotliwości) ciagnników rolniczych w warunkach polowych. Journal of Research and Applications in Agricultural Engineering 49.3: 13-16.

AUGUSTYŃSKA D., PLEBAN D., MIKULSKI W. 2000: Hałas maszyn - znormalizowane metody wyznaczania poziomu mocy akustycznej. Cz. 1. Bezpieczeństwo Pracy: Nauka i Praktyka 10: 7-13.

ANISZEWSKA M., GENDEK A. 2014: Comparison of heat of combustion and calorific value of the cones and wood of selected forest tree species. Forest Research Papers 75 (3): 231-236. DOI: 10.2478/frp-2014-0022.

ANISZEWSKA M., GENDEK A. 2016a: Logistics of the supplies of selected forest tree species' cones. Part 1. Cone density and substitution coefficient. Annals of Warsaw University of Life Sciences - SGGW, Agriculture (Agricultural and Forest Engineering) 67: 121-130.

ANISZEWSKA M., GENDEK A. 2016b. Logistics of delivery of cones of selected species of forest trees. Part 2: Cone transport. Annals of Warsaw University of Life Sciences - SGGW, Agriculture (Agricultural and Forest Engineering) 68: 113-121

ANISZEWSKA M., KUSZPIT D. 2015: Analysis of Acquisition and Potential Usage of Conifer
Cones from Polish Seed Extraction Houses between 2009-2012. Annals of Warsaw University of Life Sciences - SGGW, Agriculture (Agricultural and Forest Engineering) 65: 93-101

BEDNARZ S., URBA R. 2003: Pomiary hałasu urządzeń wiertniczych oddziałującego na środowisko naturalne. WUG: bezpieczeństwo pracy i ochrona środowiska w górnictwie 2: 13-18.

GOLEC M., GOLEC Z., CEMPEL C. 2006: Hałas turbiny wiatrowej VESTAS V80 podczas eksploatacji. Diagnostyka 1 (37): 115-120.

GÓRSKI M. 2014. Ochrona przed hałasem. In: M. Górski (Ed.). Prawo ochrony środowiska. Wolters Kluwer, Warszawa.

INGIELEWICZ R., ZAGUBIEŃ A. 2013: Pomiar hałasu infradźwiękowego wokół farmy wiatrowej. Pomiary, Automatyka, Kontrola 59.

KACZMARSKA A., MIKULSKI W. 2003: Pomiary hałasu w pomieszczeniach biurowych. Bezpieczeństwo Pracy: Nauka i Praktyka 9 (386): 21-25.

MACUDA J. 2008: Pomiary hałasu środowiskowego w przemyśle naftowym i gazowniczym. Wiertnictwo, Nafta, Gaz 25 (1): 37-42.

MIKULSKI W., AUGUSTYŃSKA D. 2000: Hałas maszyn - wyznaczanie poziomu mocy akustycznej obrabiarek do drewna. Bezpieczeństwo Pracy: Nauka i Praktyka 7-8: 6-9.

MIKULSKI W., KARCZMARSKA A., KOTON J. [n.d.]. Hałas na stanowiskach pracy. Retrieved from http://docplayer.pl/3440333-Halas-na-stanowiskach-pracy-witold-mikulskianna-karczmarska-jolanta-koton.html [access 10 December 2016].

PAWLACZYK-ŁUSZCZYŃSKA M., KOTON J., ŚLIWIŃSKA-KOWALSKA M., AUGUSTYŃSKA D., KAMEDUŁA M. 2001: Hałas ultradźwiękowy - Dokumentacja proponowanych wartości dopuszczalnych poziomów narażenia zawodowego. Metody i Podstawy Oceny Środowiska Pracy 17, 2 (28): 55-88.

PAWLACZYK-ŁUSZCZYŃSKA M., DUDAREWICZ A., ŚLIWIŃSKA-KOWALSKA M. 2007: Źródła ekspozycji zawodowej na hałas ultradźwiękowy - ocena wybranych urządzeń. Medycyna Pracy 58 (2): 105-116. 
PN-EN ISO 11201:1999. Akustyka. Hałas emitowany przez maszyny i urządzenia. Pomiar poziomów ciśnienia akustycznego emisji na stanowisku pracy i w innych określonych miejscach metodą techniczną w warunkach zbliżonych do pola swobodnego nad płaszczyzną odbijającą dźwięk.

PN-N-01307:1994. Hałas. Dopuszczalne wartości hałasu w środowisku pracy. Wymagania dotyczące wykonywania pomiarów.

PN-N-18002:2011. Systemy zarządzania bezpieczeństwem i higieną pracy. Ogólne wytyczne do oceny ryzyka zawodowego.

SADOWSKI J. 2013: Ocena hałasu na stanowiskach pracy i jego minimalizacja. Inżynieria i Aparatura Chemiczna 2: 110-112.

SARNOWSKA G., WIĘSIK J. 1997a: Wyłuszczarnia w Czarnej Białostockiej. Część 1. Proces technologiczny i przygotowanie szyszek do łuszczenia. Przegląd Techniki Rolniczej i Leśnej 11: 12-13.

SARNOWSKA G., WIĘSIK J. 1997b: Wyłuszczarnia w Czarnej Białostockiej. Część 2. Proces wyłuszczania i obróbki nasion. Przegląd Techniki Rolniczej i Leśnej 12: 8-10.

SARNOWSKA G., WIĘSIK J. 1998: Wyłuszczarnia w Czarnej Białostockiej. Część 3. Czyszczenie i separacja nasion. Przegląd Techniki Rolniczej i Leśnej 1: 19-21.

SKARŻYŃSKI J., LIPIŃSKI R. 2013: Effect of kerf height on noise emission level in the internal combustion chain saw Stihl MS 211 and the electric chain saw Stihl E 180C during cross cutting of wood. Annals of Warsaw University of Life Sciences - SGGW, Agriculture (Agricultural and Forest Engineering) 62: 55-62

SKARŻYŃSKI J., WÓJCIK K., MACKIEWICZ J. 2009: Ocena zagrożenia hałasem operatora pilarki spalinowej podczas okrzesywania i przerzynki. Zeszyty Problemowe Postępów Nauk Rolniczych 543: 309-317.

TOMASZEWSKI F., ORCZYK M. 2007: Ocena poziomu hałasu wewnątrz tramwajów na podstawie badań. Pojazdy Szynowe 4: 1-6.
WIĘSIK J., ANISZEWSKA M. 2012: Urządzenia techniczne w produkcji leśnej. In: Urządzenia do hodowli i ochrony lasu. Wydawnictwo SGGW, Warszawa.

WILKUS S. 2007: Hałas na stanowiskach pracy ubojni bydła. Inżynieria Rolnicza 11: 235-242.

Streszczenie: Ocena poziomu hałasu w wybranych wyluszczarniach nasion. $\mathrm{W}$ artykule podano wyniki pomiarów hałasu w hali wyłuszczania szyszek oraz w pomieszczeniach biurowych wyłuszczarni pracującej w nadleśnictwie Czarna Białostocka oraz Grotniki. Pomiary przeprowadzono przy stanowiskach roboczych podczas pracy maszyn. Otrzymane wyniki skonfrontowano z obowiązującymi normami i przepisami w zakresie dopuszczalnego poziomu hałasu na stanowiskach pracy. Według wyników $\left(L_{\text {Aeq, T }}\right)$ na hali produkcyjnej, gdzie hałas osiaga wartość powyżej $80 \mathrm{~dB}(\mathrm{~A})$, w obu wyłuszczarniach ryzyko narażenia na hałas określone zostało jako średnie. Uzyskane wyniki wskazują, że najistotniejszym źródłem emisji hałasu w wyłuszczarni Czarna Białostocka jest mechaniczny wytrząsacz nasion, a w Grotnikach wyciąg współpracujący z mechanicznym wytrząsaczem. W pomieszczeniach biurowych bezpośrednio przylegających do hali wyłuszczania nasion ryzyko narażenia na hałas określono jako małe.

\section{MS received January 2017}

\section{Authors' addresses:}

Monika Aniszewska, Arkadiusz Gendek, Jan Skarżyński

Wydział Inżynierii Produkcji SGGW

Katedra Maszyn Rolniczych i Leśnych

02-787 Warszawa, ul. Nowoursynowska 164

Poland

e-mail: monika_aniszewska@sggw.pl

arkadiusz_gendek@sggw.pl

jan_skarzynski@sggw.pl 